\title{
Three new Critically Endangered Inversodicraea (Podostemaceae) species from Tropical Africa: I. senei, I. tanzaniensis and I. botswana
}

\author{
Martin Cheek $^{1}$ (D) Olivier Séné ${ }^{2}$ \& Eric Ngansop ${ }^{3}$
}

Summary. Three new species of Inversodicraea (Podostemaceae), I. senei from the Memv'ele falls of the Ntem River, Cameroon, I. tanzaniensis from the Ruhudji River near Lupembe, Southern Highlands, Tanzania, and I. botswana from the Kasane rapids on the Chobe River, Botswana, are described and illustrated. All three species are known from single sites. All three are assessed as Critically Endangered using the IUCN standard. With 35 species, Inversodicraea is the most species-diverse genus of Podostemaceae in continental Africa, to which it is endemic. Four species of Inversodicraea are now known to be sympatric and point endemics at Memv'ele Falls in Cameroon where a hydro-electric dam is being constructed, threatening them with global extinction. Equally, I. tanzaniensis is threatened by proposed hydro-electric projects in Tanzania. In contrast, I. botswana is threatened by sewage discharge and also by bridge construction.

Key Words. Botswana, Cameroon, extinct, hydroelectric, rheophytes, Tanzania, waterfalls.

\section{Introduction}

Inversodicraea Engl. has been resurrected to accommodate those species previously included in Ledermanniella subg. Phyllosma C.Cusset (Thiv et al. 2009; Schenk et al. 2015; Cheek \& Haba 2016a). Inversodicraea is distinguished from Ledermanniella by the presence of scale-leaves (absent in Ledermanniella), and by having terete or laterally compressed leaf petioles (in Ledermanniella canaliculate or dorsiventrally compressed) (Cheek et al. 2017a). This paper builds on the recent synoptic account of Inversodicraea which recognised 30 species (Cheek et al. 2017a). Subsequently two more species were discovered, Inversodicraea tassing Cheek, and I. koukoutamba Cheek (Cheek et al. 2019b). Material collected in Cameroon, Tanzania and Botswana represents three additional new species which are described in this paper as I. senei Cheek, I. tanzaniensis Cheek and I. botswana Cheek respectively. This increases to 35 the number of species in Inversodicraea, the most species-diverse genus of Podostemaceae in Africa, ahead of Ledermanniella Engl. which has 30 species.

Approximately 2000 new flowering plant species are described each year (Willis 2017), adding to the estimated 369,000 already known to science (Nic Lughadha et al. 2016) although this total is disputed (Nic Lughadha et al. 2017). Widespread species tend to have already been discovered, so that many newly discovered species are range-restricted and so are much more likely to be threatened, such as those three described in this paper. Evidence-based conservation assessments exist for about $21-26 \%$ of known species, and $30-44 \%$ of these assessments rate the species concerned as threatened (Bachman et al. 2018). This makes it imperative to discover and publish such species so that they can be assessed, and so that, if merited, conservation actions can be taken to reduce their extinction risks, such as through designating and implementing Important Plant Areas (Darbyshire et al. 2017; continuously updated).

Podostemaceae are a pantropical family of annual or perennial herbs placed in Malpighiales in a sister relationship with Hypericaceae (Ruhfel et al. 2011). There are about 300 species globally, in c. 54 genera (Koi et al. 2012). Species numbers are highest in tropical America, followed by Asia, with Africa having c. 90 species. All species of the family are restricted to rocks in rapids and waterfalls of clear-water rivers, and are therefore rheophytes. However this very habitat is being increasingly exploited for hydropower at great risk to the survival of the Podostemaceae they contain (Schenk et al. 2015; Cheek et al. 2015; Cheek \& Ameka 2016; Cheek et al. 2017a, b) and these have resulted in documented extinctions e.g. in Guinea Inversodicraea pygmaea G.Taylor (Cheek 2018; Cheek \& Magassouba 2018) and I. abbayesii (G.Taylor) Cheek (Cheek \& Diop

\footnotetext{
Accepted for publication 20 June 2020. Published online 24 August 2020

1 Science, Royal Botanic Gardens, Kew, Richmond, Surrey, TW9 3AE, U.K. e-mail: m.cheek@kew.org

2 USDA, US Forest Service, International Programs, Bastos, Yaoundé, BP 35469, Cameroon

3 IRAD-Herbier National du Cameroun, Yaoundé, BP 1601, Cameroon
} 
2018), and in Angola Ledermanniella lunda Cheek (Cheek et al. 2015). Most of the African species of Podostemaceae are narrow endemics, many being species known from only a single waterfall. New discoveries of species are still being made frequently (Schenk et al. 2015; Cheek \& Ameka 2008, 2016; Cheek \& Haba 2016a; Cheek et al. 2015, 2017a, b, 2019b; Beentje 2005; Schenk \& Thomas 2004; Rial 2002; Cheek 2003; Kita et al. 2008, and also, recently, a new genus, Cheek \& Lebbie 2018).

The current generic classification of African Podostemaceae is based on the framework established by Cusset (1973, 1974, 1978, 1983, 1984, 1987 and 1997). This work has been compiled and updated by Rutishauser et al. (2004) who recognise c. 85 species in 16 genera. Recently, combined morphological and molecular phylogenetic studies of African Podostemaceae have shown that Ledermanniella (as delimited by Cusset) is paraphyletic, including all other sampled genera of Podostemaceae recognised in Africa (Thiv et al. 2009, employing plastid markers matK, trnD-trn T, rpoB-trnC in sampling 9 genera and 17 species of African Podostemaceae, and Schenk et al. (2015), employing plastid markers matK, trnL, rpoB$t r n \mathrm{C}, n d h \mathrm{~F}, r b c \mathrm{~L}$ and mat $\mathrm{R}$ in sampling 10 genera and 27 species of African Podostemaceae).

Molecular phylogenetic sampling of African Podostemaceae has been only c. $30 \%$ complete at species level (Cheek et al. 2017a). Thiv et al. (2009) and Schenk et al. (2015), have convincingly shown that Ledermanniella subg. Phyllosma C.Cusset forms a wellsupported clade of species that are sister to the rest of all other African Podostemaceae sampled, comprising Ledermanniella subg. Ledermanniella and, embedded within it, seven smaller genera: Macropodiella, Winklerella, Djinga, Dicraeanthus, Leiothylax, Letestuella and Stonesia. Thiv et al. (2009) and Schenk et al. (2015) both advocate resurrecting the generic name Inversodicraea Engl., as the oldest generic name for the species of Ledermanniella subg. Phyllosma and both transfer species formerly included under the last taxon to Inversodicraea. The last seven remaining species names of subg. Phyllosma for which formal transfer was necessary were placed into Inversodicraea in Cheek \& Haba (2016a). A synoptic revision of Inversodicraea, with six new species, was recently published (Cheek et al. 2017a).

\section{Materials and Methods}

New names were made according to the Code of Botanical Nomenclature (Turland et al. 2018). Names of species and authors follow the International Plant Names Index (IPNI, continuously updated). Herbarium material was examined with a Leica Wild M8 dissecting binocular microscope fitted with an eyepiece graticule measuring in units of $0.025 \mathrm{~mm}$ at maximum magnification. The drawings were made with the same equipment with a Leica 308700 camera lucida attachment. The material from Cameroon, Tanzania and Botswana which forms the subject of this paper, was derived from 1) a visit to YA, Cameroon in December 2016 when the second two authors presented the first author with material that they had collected, and; 2) material carried to the first author on loan from PSUB by Frances Murray-Hudson in 2018; 3) an anomalous specimen at $\mathrm{K}$ from Tanzania formerly attributed to Ledermanniella tenax (C.H.Wright) C.Cusset. These specimens, their dates, locations, collectors, places of deposit all indicated in the results below, were compared to material of all known species of Inversodicraea. Specimens were inspected from the following herbaria: BM, EA, FHO, HNG, K, P, PSUB, SRGH, WAG, WRSL, YA. WAG and COI specimens were not accessible since they were being digitised or their herbaria were being remodelled during the period of study. Terms used in the description follow Beentje \& Cheek (2003). The format of the descriptions follows Cheek et al. (2017a). All specimens seen are indicated "!". The conservation assessment follows the International Union for the Conservation of Nature (IUCN 2012) standard. The main online search address used for retrieving specimen data from labels at $\mathrm{P}$ was https:// science.mnhn.fr/institution/mnhn/collection/p/ item/, p00179355?listIndex $=128$ \&listCount $=610$. However, resolution of images of herbarium specimens was insufficient to confirm specimen identification. Herbarium codes follow Index Herbariorum (Thiers, continuously updated).

\section{Results \& Discussion}

Here we present the results of our morphological investigation of the materials analysed with the methods presented above, describing each of the three new species concerned, comparing them with their most closely similar species, citing the specimens upon which they are based, and indicating their synonymy, ecology, distribution, etymology and conservation status.

1. Inversodicraea senei Cheek sp. nov. Type: Cameroon, South Region, Campo, Memv'ele Falls, alt. c. 395 $\mathrm{m}$ alt., 21 Jan. 2016, Sene 1 - 18 (holotype YA!; isotypes $\mathrm{B}$ !; K!; US!).

Annual rheophytic herb $9-10 \mathrm{~mm}$ tall (in fruit). Root both crustose (c. $4 \times 4 \mathrm{~mm}$, shoots mainly from margin - Fig. 1A) and narrowly ribbon-like, c. $0.6 \mathrm{~mm}$ wide, $0.1 \mathrm{~mm}$ thick, internodes c. $2 \mathrm{~mm}$ long, with shoots lateral at nodes opposite (Fig. 1C). Haptera not observed on the specimens cited. Flowering and fruiting 
shoots $1-5 \mathrm{~mm}$ tall, erect, forking from near the base, branches diverging, $2-3(-4)$ per plant, densely clad in scale-leaves from base to apex. Scale leaves heteromorphic; at base of stem (Fig. 1G lower scale-leaves) oblong (0.4-) $0.8-1.2 \times 0.1-0.2(-0.3) \mathrm{mm}$ apex with $1-2$ minute lobes at apex; middle portion of stem (Fig. 1G upper scale-leaf) narrowly oblong 0.9 $1.2(-1.7) \times 0.1-0.3(-0.6) \mathrm{mm}$, the distal third divided into $3-4(-6)$ narrowly oblong or narrowly triangular irregular lobes $0.2-0.3(-0.4) \times 0.1-0.2$ $\mathrm{mm}$, apices rounded or abruptly acute, sinuses between lobes acute, scale-leaves progressively more slender and lobes longer and narrower towards stem apex; immediately adjacent to spathellum (Fig. 1H) shortly oblong in outline $0.2-0.4 \times 0.1-0.2 \mathrm{~mm}$, 3lobed, lobes c. $0.01 \mathrm{~mm}$ long. Leaves not observed on the specimen, possibly not produced. Spathellae single at axils of stem bifurcations, in bud part concealed in scale-leaves globose c. $1.2 \mathrm{~mm}$ diam., dehiscing irregularly, then funneliform. Pedicels $6 \mathrm{~mm}$ long. Tepals 2, filiform $0.6-0.65 \mathrm{~mm}$ long, flanking the androecium. Androecium about as long as gynoecium $(2.1-2.4 \mathrm{~mm})$, stamens two, united at base into an andropodium $0.6 \mathrm{~mm}$ long. Ovary unilocular, ellipsoid, \pm orbicular in transverse section (Fig. 1K), $1.4 \times$ $0.5-0.55 \mathrm{~mm}$, excluding a ribbed stipe $0.4 \mathrm{~mm}$ long, gynophore $0.2 \mathrm{~mm}$ long. Stigmas 2, united at base, filiform-cylindrical $0.3-0.35 \mathrm{~mm}$ long, erect. Capsule 6-ribbed, ribs prominent, about as deep as wide, commissural ribs obscure. Seeds ellipsoid c. $0.25 \times 0.1$ mm. Fig. 1

RECOGNITION. Similar to Inversodicreaea pygmaea G.Taylor in diminutive stature and shape of scale-leaves, differing in having 2 stamens (not 1), the scale-leaves of the mid stem: a) larger, $0.9-1.2(-1.7) \mathrm{mm}$ long (not $0.5-1 \mathrm{~mm}$ ), b) spreading (not appressed tightly to stem), c) median lobe not strongly demarcated from other lobes (not with median lobe twice as long as the lateral lobes).

DISTRIBUTION. Cameroon, South Region, Ntem River, known only from the Memv'ele Falls.

SPECIMENS EXAMINED. CAMEROON. South Region, Campo, Memv'ele Falls, alt. c. $395 \mathrm{~m}$ alt., 21 Jan. 2016, Sene 1 - 18 (holotype YA!; isotypes B!; K!; US!): ibid., Jan. 2016, Sene $\mathcal{E}^{2}$ Ngansop s.n. (K spirit! YA spirit!).

HABITAT. "Along the Ntem River, where the river breaks into multiple channels and goes over an escarpment in multiple waterfalls at Memv'ele, flowering as the water level recedes in the dry season". CONSERVATION STATUS. Known only from the type locality at the Memve'ele Falls on the Ntem River, site of the Memve'ele Hydropower project. Financed by China Exim Bank, and constructed by Sinohydro for the Ministry of Power and Water Resources, Cameroon, this is project designed to have a $200 \mathrm{MW}$ capacity from a reservoir of 19 million $\mathrm{m}^{3}$ resulting from an earthfill dam $20 \mathrm{~m}$ high built across the top of the falls, diverting water from the falls through a turbine house (eng.sinohydro.com / index.php? $\mathrm{m}=$ content $\& \mathrm{c}=$ index $\& \mathrm{a}=$ show $\&$ catid $=42 \ldots$ accessed 15 Feb. 2017). This project is expected to have highly negative effects on the survival of Inversodicraea senei since the dam will "direct the flow of the river away from the multiple waterfalls...........This dam will disrupt the hydrology of the site by destroying many waterfalls and flooding or filling the rocky reach of the river above the falls." (Schenk et al. 2015 in describing I. achoundongii J.J.Schenk, Herschlag \& D.W.Thomas from the same site). "our new species fits the IUCN criteria for Critically Endangered and could soon become extinct because of the dam construction and operation" (Schenk et al. 2015). This applies equally to I. senei at the same site.

Schenk et al. (2015) also cite an earlier conservation assessment of another Podostemaceae species at the same site: "In the IUCN (2012) Endangered listing for Inversodicraea annithomae (C.Cusset) Rutis. \& Thiv [the Cameroon material referred to is now known to be I. tchoutoi Cheek (Cheek et al. 2017a)] known only from the type locality in Gabon and from the Chutes de Memve'ele, Jean-Paul Ghogue wrote: "The major threat to this species in Cameroon is the dam construction planned in the only site locality of this species, the Ntem Waterfalls at Memve'ele near Nyabizan, 60 km east of Campo" (Ghogue 2017).

Since Inversodicraea senei is only known from a single location, with an estimated "area of occupancy" of 4 $\mathrm{km}^{2}$ (the preferred grid cell size of IUCN) and with threats as cited above, using IUCN (2012), we here assess its conservation status as CR B1+2ab (iii), that is Critically Endangered.

ETYMOLOGY. Named for Valery-Olivier Séné Belinga (1976 -) Cameroonian botanist, formerly of the Herbier National Camerounais (YA), now of US Forest Service, co-ordinator for Cameroon. He is a field botanist, REDD-plus specialist and ecologist. Collector with Eric Ngansop of the only known specimens of Inversodicraea senei.

LOCAL NAMES AND USES. None recorded.

NOTES. Inversodicraea senei is unusual in the genus for its minute size $(9-10 \mathrm{~mm}$ tall when in fruit), in which it is rivalled only by $I$. pygmaea G.Taylor of Guinea. Both species flower when the stems are only $1-5 \mathrm{~mm}$ tall. They also both have stems completely clad in broadly similar shaped scale-leaves. However, there are numerous points of difference in the scale-leaf size, lobation and heteromorphy (see Table 1), and while I. senei has flowers with two stamens, those of I. pygmaea have only one.

Inversodicraea senei is the fourth species of the genus unique to the Memv'ele Falls, the others being I. achoundongii, I. ntemensis (Y.Kita, Koi, Rutish. \& 

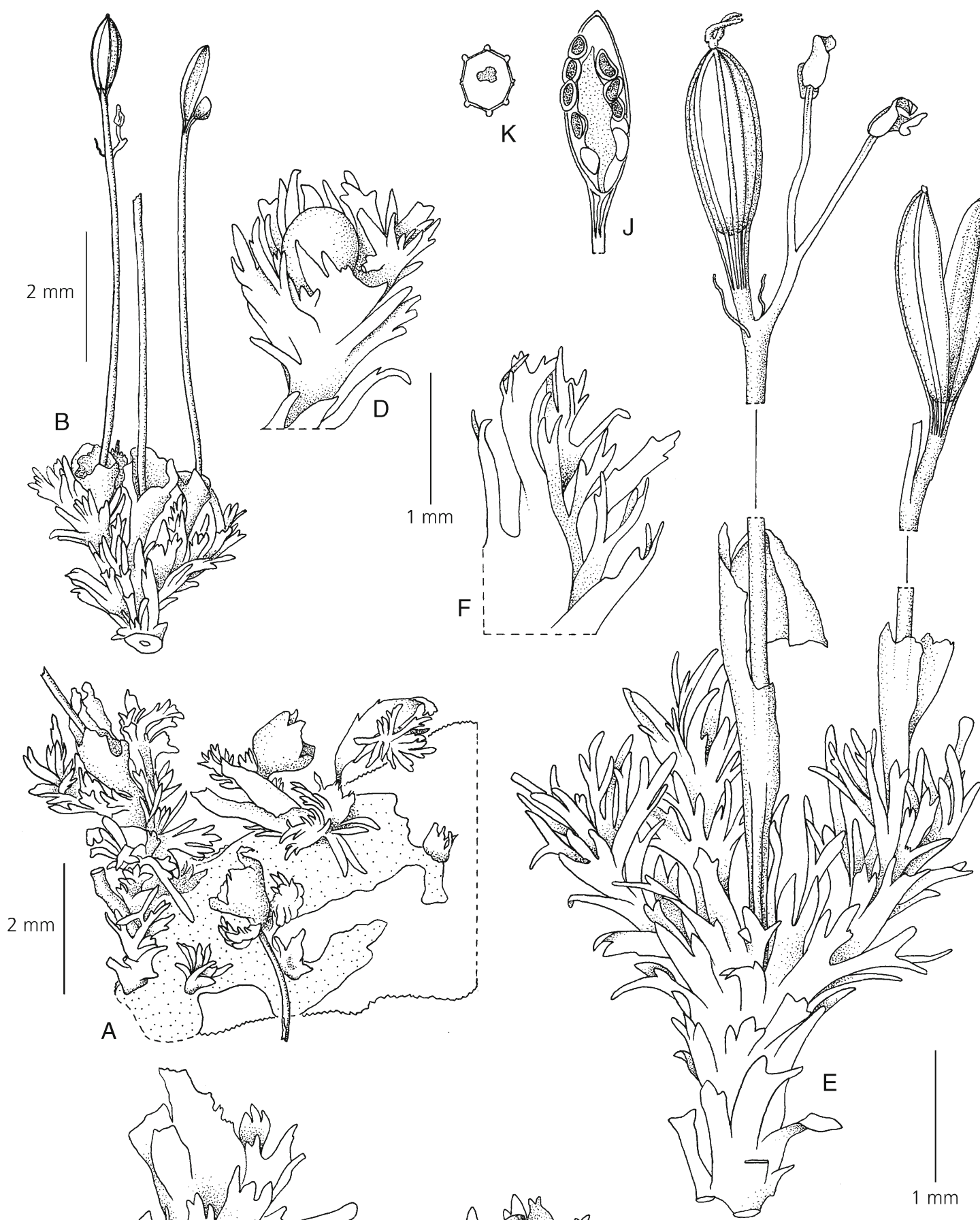

Ml
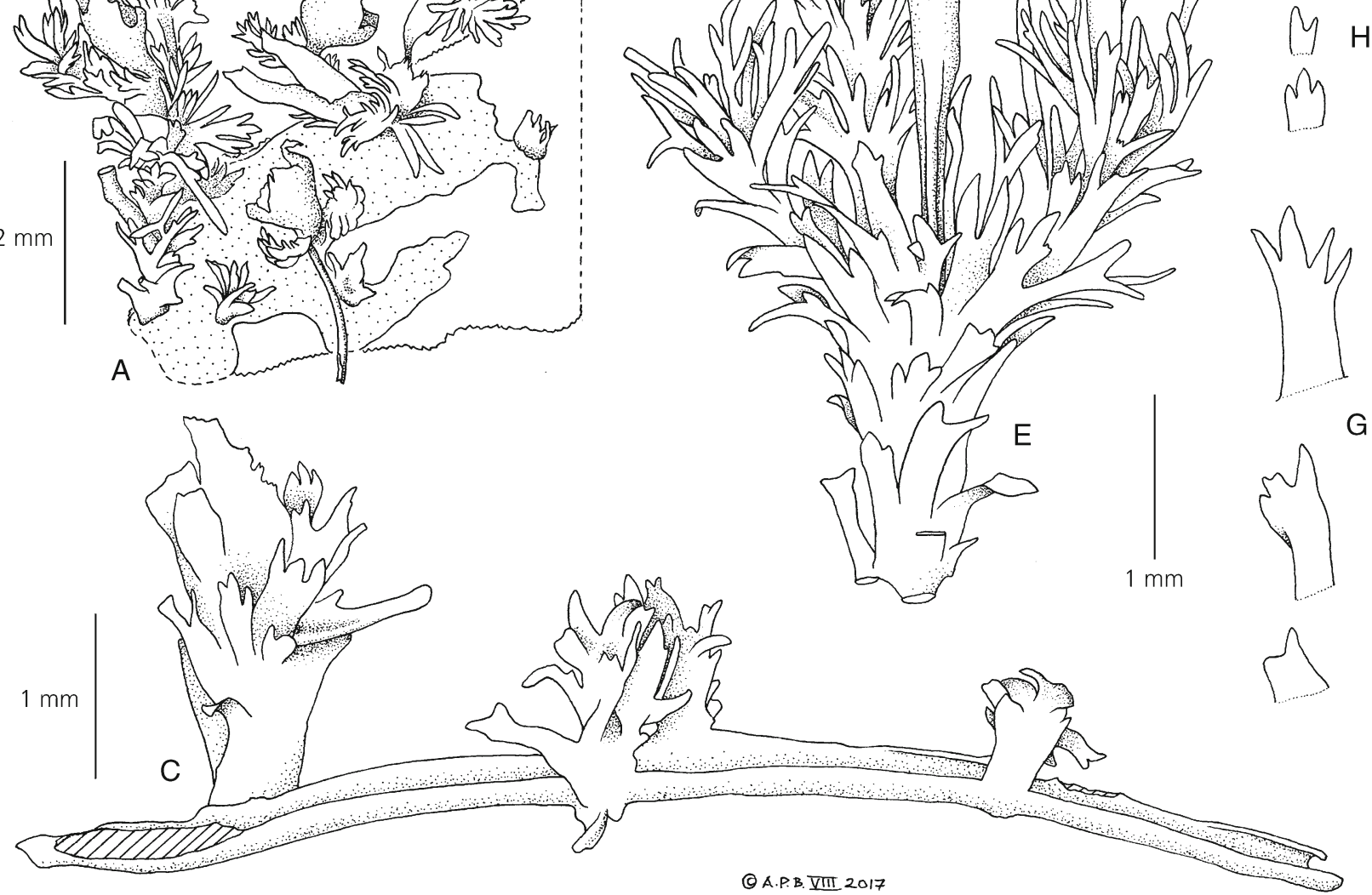

Fig. 1. Inversodicraea senei. A habit showing crustose root (dotted) with numerous shoots; B fruiting stem; C ribbon-like root with paired shoots; D shoot apex with undehisced spathellum; E flowering stem with four branches; F scale-leaves near spathellum; G individual scale-leaves from base to apex of stem; $\mathrm{H}$ minute scale-leaves from below spathellum; J ovary-fruit, one-valve removed, showing spindle-like placenta and seeds; $\mathrm{K}$ transverse section of ovary. All from the holotype Sene 123, K. DRAWN BY ANDREW BROWN. 
Table 1. Characters separating Inversodicraea pygmaea from I. senei (Characters of I. pygmaea from Taylor (1953)).

\begin{tabular}{|c|c|c|}
\hline & Inversodicraea pygmaea & Inversodicraea senei \\
\hline Scale-leaf posture & $\begin{array}{l}\text { appressed toward stem giving a } \\
\text { smooth, cylindrical appearance } \\
\text { to the leafy stem }\end{array}$ & $\begin{array}{l}\text { spreading, not appressed, giving loose, open } \\
\text { appearance to the leafy stem }\end{array}$ \\
\hline $\begin{array}{l}\text { Length of scale-leaves (from } \\
\text { mid-portion of stem) (mm) }\end{array}$ & $0.5-1$ & $0.9-1.2(-1.7)$ \\
\hline Scale-leaf lobe (sinuses) & lobes separated by rounded sinuses & lobes separated by acute sinuses, or, lobes overlapping \\
\hline Median lobe of scale-leaf & twice as long as lateral pair & slightly longer than lateral lobes \\
\hline Heteromorphy of scale-leaves & absent: scale-leaves uniform & $\begin{array}{l}\text { strongly developed: scale-leaves } \\
\text { varying in shape according to position on stem }\end{array}$ \\
\hline Anther number & 1 & 2 \\
\hline Geography & Guinea & Cameroon \\
\hline
\end{tabular}

M.Kato) J.J.Schenk, Herschlag \& D.W.Thomas, and I. tchoutoi. Therefore, these falls have the highest species diversity known globally for the genus Inversodicraea, exceeding even that of the Lobé Falls near Kribi (which has three species of Inversodicraea and seven other species of Podostemaceae). Among the three sympatric species, I. senei is most likely to be confused with the similarly small $I$. achoundongii. The last species however has deltoid (equilaterally triangular), thinly scattered scale-leaves (not rounded, lobed, densely imbricate).

From the field observations and photographs of Xander van der Burgt (pers. comm. to Cheek 2018) at these falls, niche-partitioning takes place among these species as has been reported at other falls in Cameroon occupied by multiple species of Podostemaceae (Cheek et al. 2004). Inversodicrea senei and I. achoundongii, among the smallest species in the genus, occur at higher levels in the river bed, and seem to be short-lived annuals, while I. ntemensis and I. tchoutoi, much larger, subshrubby species occur in the spray zone, lower down the river bank. However more field research is needed to map these species at the site and to clarify this matter.

New species to science are continually being discovered in Cameroon as poorly known areas are researched. Recent examples in alphabetical order are: Afrothismia kupensis Cheek (Cheek et al. 2019a) (Thismiaceae), Allophylus bertoua Cheek (Cheek \& Haba 2016b) (Sapindaceae), Brachystephanus oreacanthus Champl. (Champluvier \& Darbyshire 2009), Isoglossa dispersa I.Darbysh. \& L.J.Pearce (Acanthaceae) (Darbyshire et al. 2011) (both Acanthaceae), Microcos magnifica Cheek (Cheek 2017) (Sparrmanniaceae), Oxygyne duncanii Cheek (Cheek et al. 2018d) (Thismiaceae), Palisota ebo Cheek (Cheek et al. 2018c) (Commelinaceae), Scleria cheekii Bauters (Bauters et al. 2018), Ternstroemia cameroonensis Cheek (Cheek et al. 2017c) (Ternstroemiaceae), Vepris bali Cheek (Cheek et al. 2018b), Warneckea ngutiensis R.D.Stone (Stone \& Cheek 2018) (Melastomataceae) and the new genus Kupeantha Cheek (Cheek et al. 2018a).
2. Inversodicraea tanzaniensis Cheek sp. nov. Type: Tanzania, Distr. Iringa c. 1700 m Ruhudji River ["Stromgebie des Oberen Ruhudje, Landschaft Lupembe, nördlich des Flusses”], fl. fr. 22 Aug. 1931, Schlieben 1131A (holotype K!; isotypes B destroyed, BM!, BR, EA!,G, LISC, P!, PRE, Z, ZT).

Ledermanniella tenax (C.H.Wright) C.Cusset sensu Cusset (1983) pro parte quoad Schlieben 1131A; sensu Beentje (2005).

Rheophytic, probably annual, herb $5-8 \mathrm{~cm}$ tall. Root (basal thalloid portion) not observed by the authors. Stem erect, $1.5(-2) \mathrm{mm}$ diam. at base, unbranched for $1.5-3 \mathrm{~cm}$, then dividing into $2-4$ branches c. $1 \mathrm{~cm}$ long, those branches often bifurcating once or twice, terminating in single spathella. Stem apices $1.5-$ $2 \mathrm{~mm}$ diam., completely clothed in scale-leaves, principal stems in proximal $1 / 2-2 / 3$ sparsely covered with scale-leaves $(5-10 \%$ cover $)$. Scale-leaves \pm appressed, flattened, showing stage-dependent heteromorphy: Stage 1 (proximal $1 / 2-$ $2 / 3$ of stem): length: breadth ratio c. 1:1, triangular (towards base of stem) to bifurcate, $0.3-0.5 \times 0.3-0.5$ $\mathrm{mm}$, entire or with 2 small lateral lobes c. $0.05 \mathrm{~mm}$ long; Stage 2 (stem apices): length: breadth ratio c. 2:1, proximal part quadrangular to shortly oblong, 0.7 $-1.2 \times 0.5-0.8 \mathrm{~mm}$, distal part with $3(-4)$ subequal finger-like lobes or the central lobe slightly larger than the laterals. Stage 3 (immediately below the spathellae): length:breadth c. 4 - 5:1, linear-oblong, c. $0.8 \times 0.2 \mathrm{~mm}$, entire, or with $1-2$ minute apical teeth. Leaves, if formed, not observed. Spathella single, broadly ellipsoid, $1.2-1.5 \times 0.9-1.1 \mathrm{~mm}$, apex acute, dehiscing irregularly. Pedicel $5-5.5 \mathrm{~mm}$ long at anthesis. Tepals 2, filiform $0.8 \mathrm{~mm}$ long. Androecium of 2 stamens, exceeding ovary, andropodium $0.65 \mathrm{~mm}$ long, free filaments $1.5-1.7 \mathrm{~mm}$ long; anthers not seen on the material studied. Gynoecium with gynophore $0.25 \mathrm{~mm}$ long. Ovary unilocular, ellipsoid in lateral view, slightly compressed in the commissural plane, $2.1 \times 1.0 \times 0.8 \mathrm{~mm}$. Styles filiform $1.2-1.3 \mathrm{~mm}$ long. Fruit oblong-elliptic $2.3 \times 0.9 \mathrm{~mm}$, with 6 


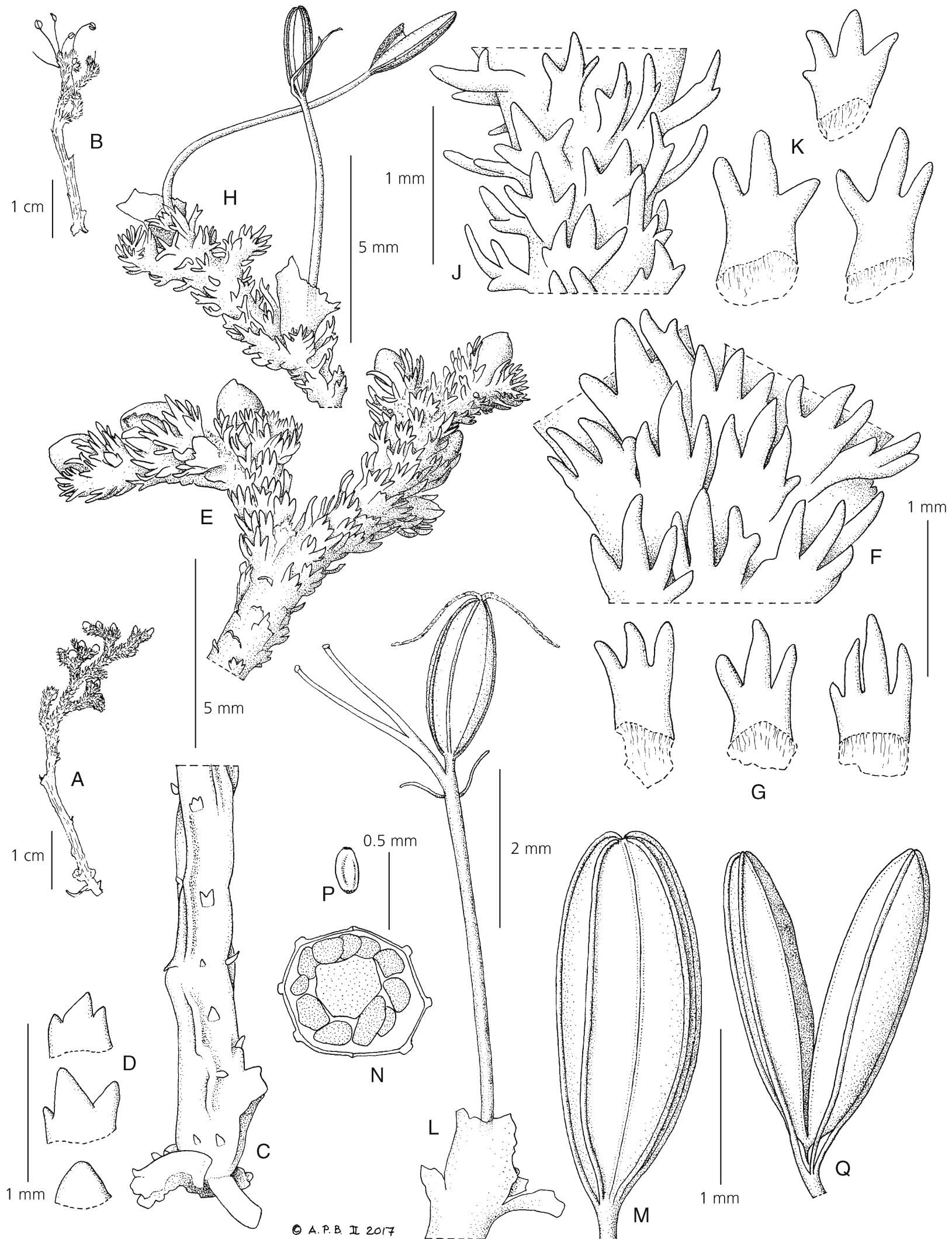

Fig. 2. Inversodicraea tanzaniensis. A habit, plant with spathelllae unopened; B habit, plant with flowers; C base of stem showing sparse scale-leaves; D scale-leaves from base of stem; $\mathrm{E}$ stem apex with unopened spathellae; $\mathrm{F}$ detail of scale-leaves from near stem apex; $\mathrm{G}$ scale-leaves from $\mathrm{F}$; $\mathrm{H}$ stems with dehisced fruits; J detail of scale-leaves from $\mathrm{H} ; \mathrm{K}$ individual scale-leaves, adaxial surface; L flower and dehisced spathellum (anthers missing); $\mathrm{M}$ undehisced fruit- note absence of commissural ribs; $\mathrm{N}$ transverse section of unilocular fruit; P seed; Q dehisced fruit. All from the holotype Schlieben 1131A, K. DRAWN BY ANDREW BROWN. 
longitudinal ribs, ribs pronounced; sutures (commissures) not pronounced. Seeds flattened ellipsoid, $0.4-0.5 \times 0.1-0.12 \mathrm{~mm}$. Fig. 2 .

RECOGNITION. Differs from Inversodicraea tenax Engl. ex R.E.Fr. in the dorsal (abaxial) surface of the scaleleaves being flat, lacking protrusions (not concave, with multiple protrusions); capsule 6-ribbed (not 8ribbed) (see Table 2 for additional diagnostic characters); it differs from I. ledermannii (Engl.) Engl. in the scale-leaves sparse on the proximal $2 / 3$ of the principal axis (not densely covered to base); capsule 6-ribbed (not 8-ribbed); stigma lobes $1.2-1.3 \mathrm{~mm}$ long (not 0.4 - $0.5 \mathrm{~mm}$ ); pollen in monads (not in diads) (see Table 3 for additional diagnostic characters).

DISTRIBUtION. Tanzania, "Southern Highlands, Njombe District" Ruhudje (now Ruhidji) River.

SPECIMENS EXAMINED. TANZANIA. Iringa Distr., Ruhudji R., c. $1700 \mathrm{~m}$ alt. ["Stromgebie des Oberen Ruhudje, Landschaft Lupembe, nördlich des Flusses”], fl. fr. 22 Aug. 1931, Schlieben 1131A (holotype K!; isotypes B destroyed, BM!, BR, EA!,G, LISC, P!, PRE, Z, ZT).

HABITAT. On rocks in rapids (presumably); $1700 \mathrm{~m}$ altitude.

Inversodicraea tanzaniensis achieves the highest altitude of all members of the genus (1700 m according to the label of the type specimen), exceeding the previously stated upper altitudinal limit of the genus held by I. digitata H.E.Hess in Angola at $1642 \mathrm{~m}$ (Cheek et al. 2017a: 129). The vast majority of the species of the genus are lowland, occurring below $800 \mathrm{~m}$ alt. (Cheek et al. 2017a). Seventeen days before collecting 1131A, Schlieben collected the type of another rheophytic species, the more widespread (Angola to Tanzania) Hydrostachys insignis Mildbr. \& Reimers (Hydrostachyaceae)(https:// plants.jstor.org/stable/viewer/ $10.5555 /$ al.ap.specimen.b\%2010\%200160108) and it is possible that the two species grew together since the name of the river, Ruhudje (now Ruhidji) is the same and the town cited is again Lupembe. However, given the separation in time, and the fact that the last specimen is given an altitude of $1600 \mathrm{~m}$ not $1700 \mathrm{~m}$, this is far from certain.

CONSERVATION STATUS. Known from the type specimen only. Although the general area is given on the label, and although Lupembe is a famous collecting locality of Schlieben's with many types of other species recorded, the exact site of the Schlieben rapids or falls on the Ruhidji River (also spelled Ruhidge, Ruhudji and Ruhiji according to Polhill 1988), is unknown. The general area is now intensively cultivated for tea (Camellia sinensis L.) as can be seen on Google Earth. This gives concern that the river that in 1931 hosted Podostemaceae might by now have lost many or possibly all of these plants due to surface run-off. Silt and algal growth due to oligotrophic conditions resulting from addition of nutrients from silt are anathema to Podostemaceae. In addition, a dam for a 358 MW hydroelectric project is planned on the Ruhidji at a site c. $75 \mathrm{~km} \mathrm{E}$ of Njombe (Anon. 2011; World Bank 2011). Such hydroelectric projects have resulted in extinction of Podostemaceae species at other sites in Africa (see introduction). When the Ruhidji dam is constructed, a total of $38 \mathrm{~km}$ length of the river, both above the dam and below, will be altered hydrologically (World Bank 2011) and so rendered unsuitable for Podostemaceae survival. Funding for the dam and other power generating projects is still being sought in Tanzania (Akinocho 2018). Apart from this major hydro project, micro hydro projects are planned in Tanzania, one of which is mapped on the Ruhidji at a white-water water length of the river (viewed on Google Earth Jan. 2020) immediately south of Njombe at $9.397 \mathrm{~S}, 34.7 \mathrm{E}$ (Dotet 2018) which is also potentially a site for Inversodicraea tanzaniensis.

The site of the type location may be (or may have been) $9^{\circ} 18^{\prime} 30.66 ” \mathrm{~S}, 35^{\circ} 11^{\prime} 19.7 ” \mathrm{E}$ (1506 m elevation reading from Google Earth). Here, $6 \mathrm{~km}$ from Lupembe, a set of rapids can be seen on Google Earth. However, Polhill (1988) records as a botanical collection locality for Eggeling and others (although Schlieben is not mentioned) the Ruhidji Falls at $9^{\circ} 21^{\prime} \mathrm{S}, 34^{\circ} 45^{\prime} \mathrm{E}$ which is the proposed location for the micro hydro project discussed above, and which may also be at risk from flooding from the dam of the proposed major hydro project at Ruhidji. Fieldwork is needed to visit the area to attempt to rediscover this species and assess the threats and develop a conservation management plan, if indeed Inversodicraea tanzaniensis still survives.

In recent decades considerable effort has been invested by numerous competent botanists (e.g. Mbago, Ndangalasi, Vollesen, Bidgood, Goyder, Darbyshire, Gereau, Lovett, Luke) in botanical inventory in the Southern Highlands of Tanzania, yet this species has not been recollected. This suggests that it may either be extinct, or that it is extremely rare and local.

ETYMOLOGY. Named for Tanzania, being both unique to that country and the only species of the genus known in Tanzania.

LOCAL NAMES AND USES. None recorded.

NOTES. Inversodicraea tanzaniensis has the distinction of being the only species of the genus known from $\mathrm{E}$. Africa (both Uganda and Kenya lack Inversodicraea). Although Cusset (1983) listed numerous specimens of I. tenax as occurring in Tanzania, these specimens are in fact all from Zambia at the Victoria Falls (with the exception of Schlieben 1131A which is I. tanzaniensis).

Cusset (1983) treated Schlieben 1131A as Inversodicraea tenax (as (Ledermanniella tenax (C.H.Wright) C.Cusset) and was followed by Beentje (2005). However, this collection lacks the main spot character for I. tenax, that is, the multiple projections 
Table 2. Diagnostic characters separating Inversodicraea ledermannii and I. tanzaniensis - characters for I. ledermannii taken from Cusset (1983).

\begin{tabular}{lll}
\hline \hline & \multicolumn{1}{c}{ Inversodicraea ledermannii } & Inversodicraea tanzaniensis \\
\hline Pedicel length post-anthesis $(\mathrm{mm})$ & $3-4$ & $6-8.2$ \\
Tepal length $(\mathrm{mm})$ & $0.3-0.4$ & 0.8 \\
Pollen & diads & monads \\
Stigma length $(\mathrm{mm})$ & $0.4-0.5$ & $1.2-1.3$ \\
Capsule rib numbers & 8 & 6 \\
Scale-leaf shape & concave & flat \\
Scale leaf coverage of stems & entire stem covered densely $1 / 3$ to $1 / 4$ densely covered in scale leaves \\
Altitudinal range $(\mathrm{m})$ & $0-400$ & 1700 \\
Geographical range & Sierra Leone to Gabon & SW Tanzania \\
\hline
\end{tabular}

from the dorsal surface of the scale-leaves. The two entities also differ in the number of ribs in the fruit capsule (6 vs 8 ), the Schlieben material lacking the commissural ribs seen in I. tenax. In addition, I. tanzaniensis differs in larger tepals, a shorter gynophore and, much shorter stems. See Table 3 for additional diagnostic characters. The distribution of specimens of the type is largely taken from Cusset (1983: 384).

Although long known for their high species diversity and numerous endemics, new species continue to be discovered frequently from the highlands of Tanzania e.g. Cheek \& Bridson (2019). Inversodicraea tanzaniensis is a rare, remote outlier of this predominantly lowland, Guineo-Congolian genus in the highlands of Tanzania, far to the East of most of the rest of the genus which has its greatest diversity in Lower Guinea (specifically Cameroon and Gabon, Cheek et al. 2017a). Similar examples, of eastern outliers of otherwise predominantly lowland, Guineo-Congolian genera that are isolated, rare, threatened and occur in the highlands of Tanzania are Afrothismia mhoroana Cheek \& Jannerup (Cheek \& Jannerup 2005), Ancistrocladus tanzaniensis Cheek (Cheek et al. 2000), Kupea jonii Cheek (Cheek 2004), Mischogyne iddii Gosline (Gosline et al. 2019), Octoknema orientalis Mildbr. (Gosline \& Malécot 2011) and Octolobus spectabilis Welw. (Cheek \& Frimodt-Møller 1998).

3. Inversodicraea botswana Cheek sp. nov. Type: Botswana, Chobe River, Kasane Rapids, c. 1746.7'S, $25^{\circ} 10^{\prime} \mathrm{E}$, "in sites subject to higher water velocities; desiccated plant growth overlying basalt rocks in riverbed in area currently not flooded. Some plants still firmly attached to the rocks", fl. fr., 9 Oct. 1984, Peter A. Smith 4456 (holotype PSUB!; isotypes PSUB!; SRGH)

\section{Ledermanniella torrei C.Cusset sensu Cusset (1997) pro parte quoad Young s.n.}

Perennial herb (probably), long stems streaming in the water, $16-25 \mathrm{~cm}$ long. Root not observed, presumably ribbon-like. Stems strongly laterally compressed (flattened) along most of their length, about five times as wide as thick (Figs 3C and 3A - detail), width $1-1.5 \mathrm{~mm}$, principal axes with lateral branches $1-2(-3.5) \mathrm{cm}$ long, arising along their length, internodes $3-6(-20) \mathrm{cm}$ long; lateral shoots terminating in $2-3$ (rarely a single) spur shoot, spur shoots $1.5-3(-5) \mathrm{mm}$ long. Leaves narrowly ribbonlike, $0.6-3 \mathrm{~cm}$ long, $0.3-0.8 \mathrm{~mm}$ wide, entire or $1-3$ bifurcate, apices acute to obtuse, base not sheathed. Scale-leaves dorsiventrally flattened, loosely appressed, strongly dimorphic: a) (Fig. 3D) narrowly triangular to subulate $0.5-0.6 \mathrm{~mm}$ long, 0.1 (- 0.15) $\mathrm{mm}$ wide, tapering to an acute point; b) (Fig. 3C) irregularly tridentate $0.4-0.7(-1.2) \mathrm{mm}$ long, the two lateral lobes shorter than the median lobe, opposite and equal or alternate and usually unequal, usually arising from the middle of the length of the scale-leaf, lobes $0.1-0.7 \mathrm{~mm}$ long; scale-leaves with both types occurring mixed together, both on the distal parts of

Table 3. Characters separating Inversodicraea tanzaniensis from I. tenax (data for $I$. tenax from Cusset (1983)).

\begin{tabular}{lll}
\hline \hline & Inversodicraea tenax & Inversodicraea tanzaniensis \\
\hline Length of stems $(\mathrm{cm})$ & to 20 & $5-8$ \\
Dorsal projections from abaxial surface scale-leaves & multiple & nil \\
Number of longitudinal ribs per capsule & 8 & 6 \\
Length of tepals $(\mathrm{mm})$ & 0.5 & 0.8 \\
Gynophore length $(\mathrm{mm})$ & 0.5 & 0.25 \\
Altitudinal range $(\mathrm{m})$ & $350-1200$ & 1700 \\
Geography & Angola, Botswana, DRC, \\
& Namibia, Zambia, Zimbabwe \\
\hline
\end{tabular}


the principal axes and the lateral branches (where thinly scattered, c. $5 \%$ cover) and on the spur-shoots, where $8-15$ scale-leaves densely cover the distal c. $1 \mathrm{~mm}$ of the spur-shoot, the proximal part only sparsely covered. Spathellum terminal on the spurshoot, single, obovoid c. $1.5 \mathrm{~mm}$ long, $0.8 \mathrm{~mm}$ wide, apex rounded, base shortly stipitate, dehiscing irregularly at apex (Fig 3B). Pedicel $7-10 \mathrm{~mm}$ long (in fruit). Tepals 2, inserted at same level as the stamens, and then flanking (Fig. 3H) or inserted slightly above (Fig. 3G), filiform, $0.6-1 \mathrm{~mm}$ long. Androecium of 2 stamens, filaments free to the base, distal parts, anthers and pollen unknown (material incomplete). Gynoecium with gynophore $0.1-0.3 \mathrm{~mm}$ long (in fruit). Ovary ellipsoid (1.3 -) $1.8 \mathrm{~mm}$ long, $0.75 \mathrm{~mm}$ diam., unilocular. Styles 2, botuliform $0.2-0.25 \mathrm{~mm}$ long, apex rounded, papillate. Fruit $1.5-1.7 \mathrm{~mm}$ long, 0.7 $0.8 \mathrm{~mm}$ diam., with 8 equal longitudinal ribs, ribs moderately pronounced, broader than deep; sutural ribs flanked by two incomplete supplementary, straight ribs (Fig. 3G and 3J) which do not extend to the apex of the fruit; dehiscing by two sutures. Seeds polygonal-oblong c. $0.25 \mathrm{~mm}$ long, about as half as long as broad. Fig. 3.

RECOGNITION. Differs from all other species of Inversodicraea in that 1) the dimorphic scale-leaves occur intermixed on all branches (not segregated into different parts of the stem); 2) the filaments of the two stamens are free to the base (not united, forming an andropodium); 3) additional to the eight usual longitudinal fruit ribs are four supplementary, sutureflanking, incomplete ribs.

DISTRIBUTION. Botswana, River Chobe at Kasane.

SPECIMENS EXAMINED. BOTSWANA. Junction of the Linyanti and Zambezi Rivers. On stones in rapids, buds, July 1930, "This spot is where N. Rhodesia (now Zambia), S. Rhodesia (now Zimbabwe) and Bechuanaland Protectorate (now Botswana) meet" Dr Elaine Young s.n. (BM 001209587!); Chobe R., Kasane Rapids, c. $17^{\circ} 46.7^{\prime} \mathrm{S}, 25^{\circ} 10^{\prime} \mathrm{E}$, fl. fr., 9 Oct. 1984, Peter A. Smith 4456 (holotype PSUB!; isotypes PSUB!; SRGH)

HABITAT. On rocks in rapids of river with Tristicha trifaria Spreng., in woodland zone; $925 \mathrm{~m}$ altitude.

At the grid reference given on the type specimen, the River Chobe is about $440 \mathrm{~m}$ wide as measured on Google Earth (accessed 8 Oct. 2018). Most of the breadth of the river, at this point, for a length of $840 \mathrm{~m}$, is occupied by four longitudinal lines of rock covered by trees. Between the islands and the banks, a SW to NE diagonal line of rapids is visible, best developed from the southern, Botswanan bank from which they extend about $200 \mathrm{~m}$. This line of rapids is judged here to be the most likely site for Inversodicraea botswana.

CONSERVATION STATUS. Inversodicraea botswana is known with certainty from a single site on the Chobe
River near the town of Kasane in the NW corner of Botswana. Kasane is the northern entry point to the Chobe National Park, well known for its high density of Kalahari elephants. The Kasane area is heavily dependent on revenue from ecotourism. Therefore, development detrimental to tourism appears not to be encouraged. In addition, Botswana appears to be unusually well-managed from an environmental perspective, especially in a tropical African context. In contrast to the foregoing two species, research for this paper has not yet discovered any overwhelming threats to Podostemaceae (such as hydro-electric dams) at this site in Botswana (see below). However, low level, more insidious threats do exist (F. Murray-Hudson pers. comm. to Cheek, Dec. 2019). The biggest immediate threat may be additional nutrients entering the river such as from sewage overflow from the clinic and potentially from hotels or lodges (sewage, and fertilisers and pesticides from gardens), given the proximity of these facilities to the river. Also, there continues to be considerable disruption to the river flow during the construction of the enormous road bridge linking Botswana with Zambia at Kazangula, where the Chobe and Zambezi Rivers converge (Kazangula Bridge, continuously updated).

Therefore, Inversodicraea botswana is here assessed as Critically Endangered, CR B2a,b(i-iv), using the IUCN (2012) standard.

Possibly uniquely among the single-site endemic species of Inversodicraea published to date, I. botswana appears not to be threatened by hydro-electric projects at present. Internet searches showed that Botswana's electrical power is supplied by three coalpowered energy stations (IPFS downloaded Oct. 2018), and by imports. The intention is to increase Botswanan energy supplies not by hydroelectric projects, the principal threat to Podostemaceae species (Cheek et al. 2017a), but from gas and solar sources (USAID 2018). The Kasane site, unusually for tropical Africa, appears free of hydroelectric projects, even though there is a head of $3-4 \mathrm{~m}$ at the site (dropping from $928 \mathrm{~m}$ to $924 \mathrm{~m}$, readings from Google Earth).

ETYMOLOGY. Named as a noun in apposition for the country of Botswana, to which currently it appears to be both unique and to be the only species of the genus present.

LOCAL NAMES AND USES. None recorded.

REMARKS. The Chobe River is confluent with the Zambesi $9 \mathrm{~km}$ downstream of Kasane near the Zambian town of Kazangula. About $11 \mathrm{~km}$ downstream of the confluence, c. $25 \mathrm{~km}$ distant from the type location of Inversodicraea botswana, is the nearest likeliest site for the species, near Katambora (Zambia) at $17^{\circ} 50^{\prime} 30.09 " \mathrm{~S}, 25^{\circ} 22^{\prime} 07.86^{\prime \prime} \mathrm{E}$ and $921 \mathrm{~m}$ alt. Here the riverbed branches and white-water points scattered along the riverbed are visible on Google 


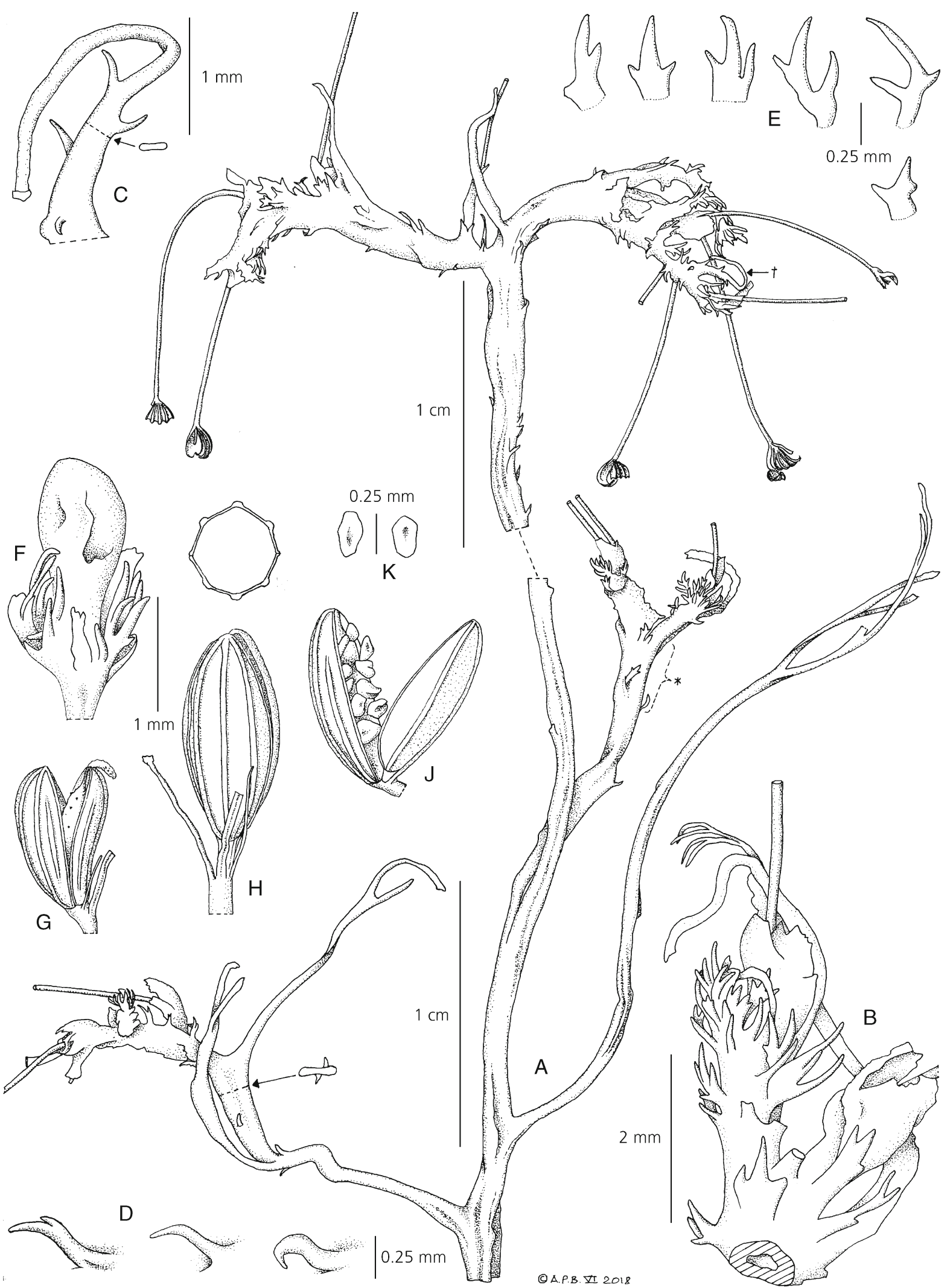

Fig. 3. Inversodicraea botswana. A habit, post-fruiting plant, with leaves; B pair of spur-shoots, densely covered in scale-leaves, with terminal dehisced spathellae; C young shoot flattened, with lateral scale-leaves; D scale-leaves subulate type; E scale-leaves: tridentate type; F spur-shoot with terminal spathellum, undehisced; $\mathrm{G}$ fruit, with stigma; $\mathrm{H}$ fruit, with two free staminal filaments and filamentous tepal; J dehisced fruit with seeds; K seeds. All from the holotype Peter A. Smith 4456, PSUB. DRAWN BY ANDREW BROWN. 
Earth (accessed Aug. 2018). The Victoria Falls, further downstream still, c. $70 \mathrm{~km}$ on a straight line at Livingstone, is the nearest documented site for Inversodicrea being the type locality for I. tenax Engl. ex R.E.Fr. and the most heavily collected site in Africa for Podostemaceae (Cheek et al. 2017a). Inversodicraea botswana is unique in the genus for three characterstates:

1) The scale-leaves on the principal axes are strongly and consistently dimorphic. Both narrowly triangular entire scale-leaves, and tridentate scale-leaves occur intermixed (Fig. 3A, D \& E). In all other species scaleleaves on the principal axes (if they occur) are monomorphic.

2) The andropodium is absent, even though two stamens are present. In all other species of Inversodicraea (in fact all other African podostemoids) with $2(-3)$ stems, the filaments are united into a common structure for part of their length: the andropodium. Although, due to the nature of the material, anthers are not present.

3) In addition to the usual 8 longitudinal ribs, a further four incomplete ribs flank the commissure as in Stonesia.

There is no doubting the identification of the free staminal filaments, subtended as they are by the filamentous tepals (Fig. 3G \& H). The species is also remarkable for the flattened principal stem axes (Fig. 3A) and for the filamentous tepals, which are amongst the longest in the genus, although not exceeding those of Inversodicraea thollonii (Baill.) Cheek (which are 1.2 - $1.5 \mathrm{~mm}$ long). More complete material of this species is still required.

The affinities of the species may not be with Inversodicraea tenax as the specimen had previously been identified, but with the species of the Angolan plateau to the west. Inversodicraea fluitans H.E.Hess, I. digitata H.E.Hess and I. warmingiana Engl. all share with I. botswana long principal axes that flow in the water, bearing scale-leaves densely on the lateral, spathellae-bearing, spur-shoots. However, none of the Angolan species has scale-leaves on the principal axis nor are these dimorphic as seen in I. botswana, nor have they flowers where the stamens have two, completely free filaments. The principal differences between $I$. botswana and I. tenax are the complete absence in the first of any of the projections from the dorsal face of the scale-leaf that characterise the second. Similarly, I. tenax lacks all three of the characters described above as being unique to I. botswana.

Botswana, in contrast to Cameroon and Tanzania, has comparatively low plant species diversity and few country endemics. Therefore, the discovery of this species is unexpected.

\section{The first collection of Inversodicraea botswana}

The earliest known collected specimen of Inversodicraea botswana is that of Dr Elaine Young s.n. (BM). The material shares the unique combination of tridentate and entire scale-leaves on the stems. However, neither flowers nor fruit are present so the other distinctive features of the species remain undetectable. Yet spathellae are present. The plants were collected three months earlier than the type gathering and perhaps for this reason, being in an earlier state, are smaller in stature, only $2-4 \mathrm{~cm}$ tall. The location given is at the junction of the Linyanti and Zambesi Rivers. However, at the confluence itself no suitable habitat (rapids) can be seen. The nearest sites with suitable habitat are 1) the type locality, $9 \mathrm{~km}$ upstream of the confluence on the Linyanti-Chobe River, and 2) $16 \mathrm{~km}$ downstream of the confluence on the Zambezi near the settlement of Katambora (on the Zambesi side). Here, at $17^{\circ} 50^{\prime} 13.09^{\prime \prime} \mathrm{S}, 2^{\circ} 22^{\prime} 07.86^{\prime \prime} \mathrm{E}$, an extensive area of rapids can be seen on Google Earth (observed 19 June 2018). If this was not the actual site of the Young collection, it is worth surveying in case I. botswana also occurs there. Upstream of the type locality the Chobe-Linyanti and tributaries form a meandering maze of channels, resembling an inland delta, in which no rapids and therefore no suitable Podostemaceae habitat, are present.

The Young specimen is identified as Ledermanniella torrei C.Cusset (now Inversodicraea torrei (C.Cusset) Cheek) by Cusset (1997). This identification is erroneous since I. torrei, a point endemic of Mount Namuli in Mozambique, has monomorphic scale-leaves with three extraordinary long and slender acute lobes. It lacks the mixed, dimorphic scale-leaves (and other distinctive features referred to above) of I. botswana.

\section{Acknowledgements}

Peris Kamau and Kennedy Matheka of EA are thanked for arranging the loan to $\mathrm{K}$ of material from their herbarium regarding Inversodicraea tanzaniensis. JeanMichel Onana former Head of IRAD-National Herbarium of Cameroon, is thanked for arranging authorisations for the fieldwork that enabled the collection by OS and EN of some of the data presented in this paper regarding I. senei. Dr Florence Ngo Ngwe is thanked for facilitating the visit to YA of MC, funded by Bentham Moxon Trust, UK that allowed the collaboration on this paper with OS and EN in December 2016.

At the Okavango Research Institute, Ms Frances Murray-Hudson, Dr Keotsheplie Kashe, Research Scholar in Plant Ecology, Mr Joseph Madome, Curator PSUB Herbarium, Mr Mmusi Mmusi, PSUB Herbarium Assistant are thanked for facilitating the loan of material from PSUB to $\mathrm{K}$, and for attempting to refind in the wild Inversodicraea botswana in July - August 2018. 
Janis Shillito is thanked for typing the manuscript. George Gosline, Frances Murray-Hudson, and two anonymous reviewers are thanked for constructive comments on an earlier draft of the paper.

Open Access This article is licensed under a Creative Commons Attribution 4.0 International License, which permits use, sharing, adaptation, distribution and reproduction in any medium or format, as long as you give appropriate credit to the original author(s) and the source, provide a link to the Creative Commons licence, and indicate if changes were made. The images or other third party material in this article are included in the article's Creative Commons licence, unless indicated otherwise in a credit line to the material. If material is not included in the article's Creative Commons licence and your intended use is not permitted by statutory regulation or exceeds the permitted use, you will need to obtain permission directly from the copyright holder. To view a copy of this licence, visit http://creativecommons.org/ licenses/by/4.0/.

\section{References}

Akinocho, G. J. (2018). Tanzania seeks $\$ 3.6$ billion for 9 energy projects. https://www.ecofinagency.com/ electricity/2709-39008-tanzania-seeks-3-6-billion-for9-energy-projects (downloaded 2 Jan. 2020).

Anon. (2011). SMEC to work on Tanzania's Ruhidji Hydro Project. Water Power $\mathcal{E}$ Construction. https:// www.waterpowermagazine.com/news/newssmec-towork-on-tanzania-s-ruhudji-hydro-project (downloaded 2 Jan. 2020).

Bachman, S., Nic Lughadha, E. M. \& Rivers, M. C. (2018). Quantifying progress towards a conservation assessment for all plants. Conserv. Biol. https:// doi.org/10.1111/cobi.13071

Bauters, K., Goetghebeur P. \& Larridon, I. (2018). Scleria cheekii, a new species of Scleria subgenus Hypoporum (Cyperaceae, Cyperoideae, Sclerieae). Kew Bull. 73: 27.

Beentje, H. (2005). Podostemaceae. Flora of Tropical East Africa. Balkema, Lisse.

\& Cheek, M. (2003). Glossary. In: H. Beentje (ed.), Flora of Tropical East Africa. Balkema, Lisse.

Champluvier, D. \& Darbyshire, I. (2009). A revision of the genera Brachystephanus and Oreacanthus (Acanthaceae) in tropical Africa. Syst. Geogr. Pl. 79 (2): 115 - 192. https://doi.org/10.2307/25746

Cheek, M. (2003). A new species of Ledermanniella (Podostemaceae) from western Cameroon. Kew Bull. 58: 733 - 737. https://doi.org/10.2307/4111153

(2004). Kupeaeae, a new tribe of Triuridaceae from Africa. Kew Bull. 58: 939 - 949. https:// doi.org/10.2307/4111207
(2017). Microcos magnifica (Sparrmanniaceae) a new species of cloudforest tree from Cameroon. PeerJ 5:e4137 https://doi.org/10.7717/peerj.4137

(2018). Inversodicraea pygmaea. The IUCN Red List of $\mathrm{T}$ h r e a t e n e d $\mathrm{S}$ p e c i e s 2018 : e.T98569037A100439967. https://doi.org/10.2305/ IUCN.UK.2018-1.RLTS.T98569037A100439967.en. (downloaded 2 Oct. 2018).

\& Ameka, G. (2008). Ledermanniella pollardiana sp.nov. (Podostemaceae) from western Cameroon. Nord. J. Bot. 26: 214 - 217. https://doi.org/10.1111/ j.1756-1051.2008.00162.x

\&__ (2016). Macropodiella cussetiana (Podostemaceae) a new species from Côte d'Ivoire. Kew Bull. 17: 2. https:/ / doi.org/10.1007/S12225-016-9634-9.

\& Bridson, D. M. (2019). Three new threatened Keetia species (Rubiaceae), from the forests of the Eastern Arc Mts, Tanzania. Gard. Bull. Singapore 71 (Suppl. 2): 155 - 169. https://doi.org/10.26492/ gbs71 (suppl.2).2019-12

\& Diop, F. N. (2018). Inversodicraea abbayesii. The IUCN Red List of Threatened Species 2018: e.T185374A124044344. https://doi.org/10.2305/ IUCN.UK.2018-1.RLTS.T185374A124044344.en. (downloaded 30 Nov. 2019).

\& Frimodt-Møller, C. (1998). The genus Octolobus (Sterculiaceae) new to East Africa. Kew Bull. 53 (3): 682.

\& Haba, P. (2016a). Inversodicraea Engl. resurrected and $I$. pepehabai sp. nov. (Podostemaceae), a submontane forest species from the Republic of Guinea. Kew Bull. 71, 4: https://doi.org/10.1007/s12225-016-9673-2

\& ____ (2016b). Spiny African Allophylus (Sapindaceae): a synopsis. Kew Bull. 71: 57. https://doi.org/10.1007/s12225-016-9672-3

\& Jannerup, P. (2005, publ. 2006). A new species of Afrothismia (Burmanniaceae) from Tanzania. Kew Bull. 60: 593 - 596. http://www.jstor.org/stable/ 25070246

\& Lebbie, A. (2018). Lebbiea (PodostemaceaePodostemoideae), a new, nearly extinct genus with foliose tepals, in Sierra Leone. PLoS ONE 13(10): e 0203603 . https://doi.org/10.1371/ journal.pone.0203603

\& Magassouba, S. (2018). L'Importance de la Conservation des Plantes en Guinée. Guide à l'Intention des Ensignants du Secondaire. Royal Botanic Gardens, Kew.

, Alvarez-Aguirre, M. G., Grall, A., Sonké, B., Howes, M-J. R. \& Larridon, I. (2018a). Kupeantha (Coffeeae, Rubiaceae), a new genus from Cameroon and Equatorial Guinea. PLoS ONE 13(6): e0199324. https://doi.org/10.1371/journal.pone.0199324

, van der Burgt, X., Momoh, J. \& Lebbie, A. (2017b). Ledermanniella yiben sp. nov. (Podostemaceae), Critically Endangered at the 
proposed Yiben Reservoir, Sierra Leone. Kew Bull. 72: 31. https://doi.org/10.1007/s12225-017-9699-0

, Etuge, M. \& Williams, S. (2019a). Afrothismia kupensis sp. nov. (Thismiaceae), Critically Endangered, with observations on its pollination and notes on the endemics of Mt Kupe, Cameroon. Blumea 64 (1): 158 - 164. https:/ /doi.org/10.3767/ blumea.2019.64.02.06

, Feika, A., Lebbie, A., Goyder, D., Tchiengue, B., Sene, O., Tchouto, P. \& van der Burgt, X. (2017a). A synoptic revision of Inversodicraea (Podostemaceae). Blumea 62: 125 - 156. https:// doi.org/10.3767/blumea.2017.62.02.07

, Frimodt-Møller, C. \& Hoerlyck, V. (2000). A new submontane species of Ancistrocladus from Tanzania. Kew Bull. 55: 207 - 212. https://doi.org/ $10.2307 / 4117778$

, Gosline, G. \& Onana, J.-M. (2018b). Vepris bali (Rutaceae), a new critically endangered (possibly extinct) cloud forest tree species from Bali Ngemba, Cameroon. Willdenowia 48: 285 - 292. https://doi.org/10.3372/wi.48.48207

, Molmou, D., Jennings, L., Magassouba, S. \& van der Burgt, X. (2019b). Inversodicraea koukoutamba and I. tassing (Podostemaceae), new waterfall species from Guinea, West Africa. Blumea 64: 216 - 224. https:/ / doi.org/10.3767/blumea.2019.64.03.03

, Pollard, B. J., Darbyshire, I, Onana, J-M. \& Wild, C. (2004). The Plants of Kupe, Mwanenguba and the Bakossi Mts, Cameroon. A Conservation Checklist. Royal Botanic Gardens, Kew.

Poveda, L. L. \& Darbyshire, I. (2015). Ledermanniella lunda sp. nov. (Podostemaceae) of Lunda Norte Angola. Kew Bull. 70: 10. https:// doi.org/10.1007/S12225-015-9559-8

, Prenner, G,. Tchiengué, B. \& Faden, R. B. (2018c). Notes on the endemic plant species of the Ebo Forest, Cameroon, and the new, Critically Endangered, Palisota ebo (Commelinaceae). Pl. Ecol. Evol. 151 (3): 434 - 441. https://doi.org/10.5091/ plecevo.2018.1503

, Tchiengue, B. \& Tacham, W. N. (2017c). Ternstroemia cameroonensis (Ternstroemiaceae), a new medicinally important species of montane tree, nearly extinct in the Highlands of Cameroon. Blumea 62, 2017: 53 - 57. https://doi.org/10.3767/ 000651917 X695362.

Tsukaya, H., Rudall, P. J. \& Suetsugu, K. (2018d) Taxonomic monograph of Oxygyne (Thismiaceae), rare achlorophyllous mycoheterotrophs with strongly disjunct distribution. PeerJ 6:e4828 https://doi.org/ $10.7717 /$ peerj. 4828

Cusset, C. (1973). Contribution à l'étude des Podostemaceae. III Le genre Stonesia. Bull. Mus. Natl. Hist. Nat., Paris, 4e sér, 6, sect. B, Adansonia 13: $307-312$.
(1974). Contribution à l'étude des Podostemaceae. VI Les genres Ledermanniella, Monandriella et Inversodicraea. Bull. Mus. Natl. Hist. Nat., Paris, 4e sér, 6, sect. B, Adansonia 14: $271-275$.

(1978). Contribution à l'étude des Podostemaceae. V Le genre Macropodiella Engl. Bull. Mus. Natl. Hist. Nat., Paris, 4e sér, 6, sect. B, Adansonia 6: 293 - 303.

(1983). Contribution à l'étude des Podostemaceae. 7 Ledermanniella Engl. Sous-genre Phyllosma C.Cusset. Bull. Mus. Natl. Hist. Nat., Paris, 4e sér. 5, sect. B, Adansonia 4: 361 - 390.

(1984). Contribution à l'étude des Podostemaceae. 8 Ledermanniella Engl. Sous-genre Ledermanniella. Bull. Mus. Natl. Hist. Nat., Paris, 4e sér, 6, sect. B, Adansonia 3: $249-278$.

(1987). Podostemaceae. Flore du Cameroun 30. MESRES, Yaoundé.

(1997). Podostemaceae. Flora Zambeziaca 9, 2: 1 10.

Darbyshire, I. (continuously updated). Tropical Important Plant Areas. http://science.kew.org/strategic-output/tropical-important-plant-areas

Anderson, S,. Asatryan, A., Byfield, A., Cheek, M., Clubbe, C., Ghrabi, Z., Harris, T., Heatubun, C. D., Kalema, J., Magassouba, S., McCarthy, B., Milliken, W., de Montmollin, B., Nic Lughadha, E., Onana, J-M., Saïdou, S., Sârbu, A., Shrestha, K. \& Radford, E. A. (2017). Important Plant Areas: revised selection criteria for a global approach to plant conservation. Biodivers. Conserv. https:// doi.org/10.1007/s10531-017-1336-6

Pearce, L. \& Banks, H. (2011). The genus Isoglossa (Acanthaceae) in west Africa. Kew Bull. 66: 425 - 439. https:/ / doi.org/10.1007/s12225-011-9292-x

Dotet, R. (2018). Small Hydro Mapping Report. Renewable Energy Resource Mapping: Small Hydro - Tanzania [P145271]. REA/World Bank. http:// d ocuments.worldbank.org / curated / en / 513901536181046309/pdf/TZ-ESMAP-RE-ResourceMapping-Small-Hydro-Study-Final-version-June2018.pdf

Ghogue, J.-P. (2017). Inversodicraea annithomae (amended version of 2010 assessment). The IUCN Red List of Threatened Species 2017 : e.T185360A120457504. https://doi.org/10.2305/ IUCN.UK.2017-3.RLTS.T185360A120457504.en. (downloaded 30 Nov. 2019).

Gosline, G. \& Malécot, V. (2011). A monograph of Octoknema (Octoknemaceae - Olacaceae s.l.) Kew Bull. 66: 367. https:/ /doi.org/10.1007/s12225-011-9293-9

Marshall, A. R. \& Larridon, I. (2019). Revision and new species of the African genus Mischogyne (Annonaceae). Kew Bull. 74: 28. https://doi.org/ $10.1007 /$ s12225-019-9804-7

IPFS (downloaded Oct. 2018). https://ipfs.io/ipfs/ QmXoypizjW3WknFiJnKLwHCnL72vedxjQkDDP1m- 
XWo6uco/wiki/List_of_power_stations_in_ Botswana.html

IPNI (continuously updated). The International Plant Names Index. http://ipni.org/.

IUCN (2012). IUCN Red List Categories and Criteria: Version 3.1. Second edition. IUCN, Gland and Cambridge.

Kazangula Bridge (continuously updated). https:// en.wikipedia.org/wiki/Kazungula_Bridge, https:/ / www.google.com/maps/place/Kazungula,+Zambia/@$17.7883952,25.2203284,8243 \mathrm{~m} /$ data $=! 3 \mathrm{~m} 1 ! 1 \mathrm{e} 3 ! 4 \mathrm{~m} 5 ! 3 \mathrm{~m} 4 ! 1 \mathrm{~s} 0 \times 195 \mathrm{a} 9 \mathrm{f} 8 \mathrm{~d} 06 \mathrm{eb} 39 \mathrm{e} 7: 0-$ x8316382bffb162e5!8m2!3d-17.7806088!4d25.2778317.

Kita, Y., Satoshi, K., Rutishauser, R. \& Kato, M. (2008). A New Species of Ledermanniella (Podostemaceae) from Cameroon. Acta Phytotax. Geobot. 59 3: 223 - 227.

Koi, S., Kita, Y., Hirayama, Y., Rutishauser, R., Huber, K. A. \& Kato, M. (2012). Molecular phylogenetic analysis of Podostemaceae: implications for taxonomy of major groups. Bot. J. Linn. Soc. 169: 461 - 492.

Nic Lughadha, E., Govaerts, R., Belyaeva, I., Black, N., Lindon, H., Allkin, R., Magill, R. E. \& Nicolson, N. (2016). Counting counts: Revised estimates of numbers of accepted species of flowering plants, seed plants, vascular plants and land plants with a review of other recent estimates. Phytotaxa 272 (1): https://doi.org/10.11646/phytotaxa.272.1.5

, Bachman, S. P. \& Govaerts, R. (2017). Plant Fates and States: Response to Pimm \& Raven. Trends Ecol. Evol. 32: 887 - 889

Polhill, D. (1988). Index of Collecting Localities. Flora of Tropical East Africa. Royal Botanic Gardens, Kew.

Rial, A. (2002). Une nouvelle espèce de Macropodiella (Podostemaceae) de Guinée Équatoriale. Adansonia 24 (2): $295-297$.

Ruhfel, B. R., Bittrich, V., Bove, C. P., Gustafsson, M. H. G., Philbrick, C. T., Rutishauser, R., Xi, Z. \& Davis, C. C. (2011). Phylogeny of the clusioid clade (Malpighiales): Evidence from the plastid and mitochondrial genomes. Amer. J. Bot. 98 (2): 306 325. https://doi.org/10.3732/ajb.1000354

Rutishauser, R., Pfeifer, E. \& Bernard, A. (2004). Podostemaceae of Africa and Madagascar: keys to genera and species, including genera description, illustrations to all species known, synonyms, and literature cited. https://www.systbot.uzh.ch/static/ podostemaceae/keys/podostemaceae_key.pdf

Schenk, J. J. \& Thomas, D. W. (2004). A New Species of Ledermanniella (Podostemaceae) from Cameroon. Nowon 14 (2): 227 - 232
Herschlag, R. \& Thomas, D. W. (2015). Describing a New Species into a Polyphyletic Genus: Taxonomic Novelty in Ledermanniella s.l. (Podostemaceae) from Cameroon. Syst. Bot. 40 (2): 539 - 552. https:// doi.org/10.1600/036364415x688330

Stone, R. D. \& Cheek, M. (2018). A revised key to the Warneckea species of Cameroon, and description of Warneckea ngutiensis (MelastomataceaeOlisbeoideae), a new Critically Endangered rainforest shrub. Kew Bull. 73: 12. https://doi.org/ $10.1007 / \mathrm{s} 12225-018-9739-4$

Taylor, G. (1953). Notes on the Podostemaceae for the revision of the Flora of West Tropical Africa. Bull. Brit. Mus. (Nat. Hist.) 1 (3): 51 - 79.

Thiers, B. (continuously updated). Index Herbariorum: A global directory of public herbaria and associated staff. New York Botanical Garden's Virtual Herbarium. http://sweetgum.nybg.org/ih/

Thiv, M., Ghogue, J-P., Grob, V., Huber, K., Pfeifer, E. \& Rutishauser, R. (2009). How to get off the mismatch at the generic rank in African Podostemaceae? Pl. Syst. Evol. 283: 57 - 77. https://doi.org/10.1007/s00606-009-0214-4

Turland, N. J., Wiersema, J. H., Barrie, F. R., Greuter, W., Hawksworth, D. L., Herendeen, P. S., Knapp, S., Kusber, W-H., Li, D-Z., Marhold, K., May, T. W., McNeill, J., Monro, A. M., Prado, J., Price, M. J. \& Smith, G. F. (eds) (2018). International Code of Nomenclature for algae, fungi, and plants (Shenzhen Code) adopted by the Nineteenth International Botanical Congress. Shenzhen, China, July 2017. Regnum Veg. 159. Koeltz Botanical Books, Glashütten.

USAID (2018). Botswana Power Fact Sheet. Downloaded 8 Oct. 2018: https://www.usaid.gov/powerafrica/ botswana

Willis, K. (ed). (2017). State of the World's Plants Report 2017. Royal Botanic Gardens, Kew.

World Bank (2011). Tanzania - Private Power Generation (Ruhudji HPP) Project (English). World Bank, W a s h i g t o n, D C. h t t p : / / documents.worldbank.org / curated/en / 245241468308947842/Tanzania-Private-PowerGeneration-Ruhudji-HPP-Project

\section{Publisher's Note}

Springer Nature remains neutral with regard to jurisdictional claims in published maps and institutional affiliations. 